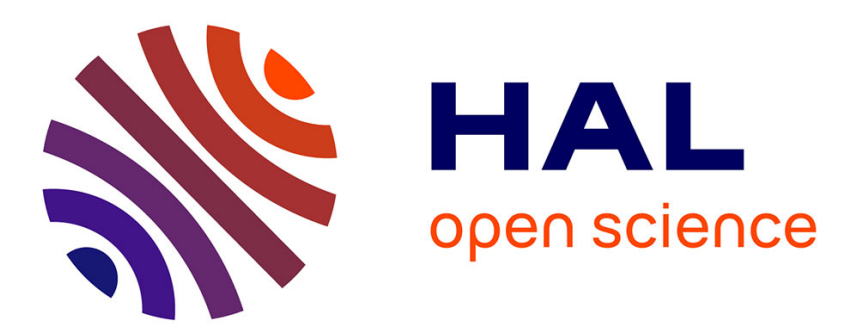

\title{
Interpreting CO2-SIc relationship to estimate CO2 baseline in limestone aquifers
}

Nicolas Peyraube, R. Lastennet, A. Denis, P. Malaurent, J.D. Villanueva

\section{To cite this version:}

Nicolas Peyraube, R. Lastennet, A. Denis, P. Malaurent, J.D. Villanueva. Interpreting CO2-SIc relationship to estimate CO2 baseline in limestone aquifers. Environmental Earth Sciences, 2015, 1, pp.19-26. 10.1007/s12665-014-3316-4 . insu-01021139

\section{HAL Id: insu-01021139 \\ https://hal-insu.archives-ouvertes.fr/insu-01021139}

Submitted on 9 Jul 2014

HAL is a multi-disciplinary open access archive for the deposit and dissemination of scientific research documents, whether they are published or not. The documents may come from teaching and research institutions in France or abroad, or from public or private research centers.
L'archive ouverte pluridisciplinaire HAL, est destinée au dépôt et à la diffusion de documents scientifiques de niveau recherche, publiés ou non, émanant des établissements d'enseignement et de recherche français ou étrangers, des laboratoires publics ou privés. 


\title{
Interpreting $\mathrm{CO}_{2}$-SIc relationship to estimate $\mathrm{CO}_{2}$ baseline in limestone aquifers
}

N.Peyraube ${ }^{\mathrm{a}, \mathrm{b}, *}$, R.Lastennet $^{\mathrm{b}}$, A.Denis ${ }^{\mathrm{b}}$, P.Malaurent $^{\mathrm{b}}$, J.D.Villanueva $^{\mathrm{b}, \mathrm{c}}$

${ }^{a}$ CNRS Orleans, ISTO, Orléans, France

${ }^{\mathrm{b}}$ University of Bordeaux, I2M-GCE, Talence, France

${ }^{\mathrm{c}}$ University of the Philippines at Los Baños, SESAM, College, Philippines

*Corresponding author. Tel +33 238492596, peyraube@ hotmail.fr

\begin{abstract}
Saturation index with respect to calcite (SIc) and equilibrium $\mathrm{CO}_{2}$ partial pressure are important parameters to study groundwater in limestone aquifers. Aside from their use in time series, $\mathrm{CO}_{2}$ and SIc are used to estimate the baseline of $\mathrm{CO}_{2}$ in the vadose zone. The objective of this paper is to present conceptual examples on the use of the $\mathrm{CO}_{2}$-SIc relationship in order to have new information from usual parameters. Case study was considered as an example of use from Cussac site, a limestone aquifer in Southwest of France. The result showed that $\mathrm{CO}_{2}$ base line in unsaturated zone is found close to $25000 \pm 1000 \mathrm{ppm}$.
\end{abstract}

Key words: $\mathrm{CO}_{2}$ baseline, carbonate rock, unsaturated zone

\section{Nomenclature}

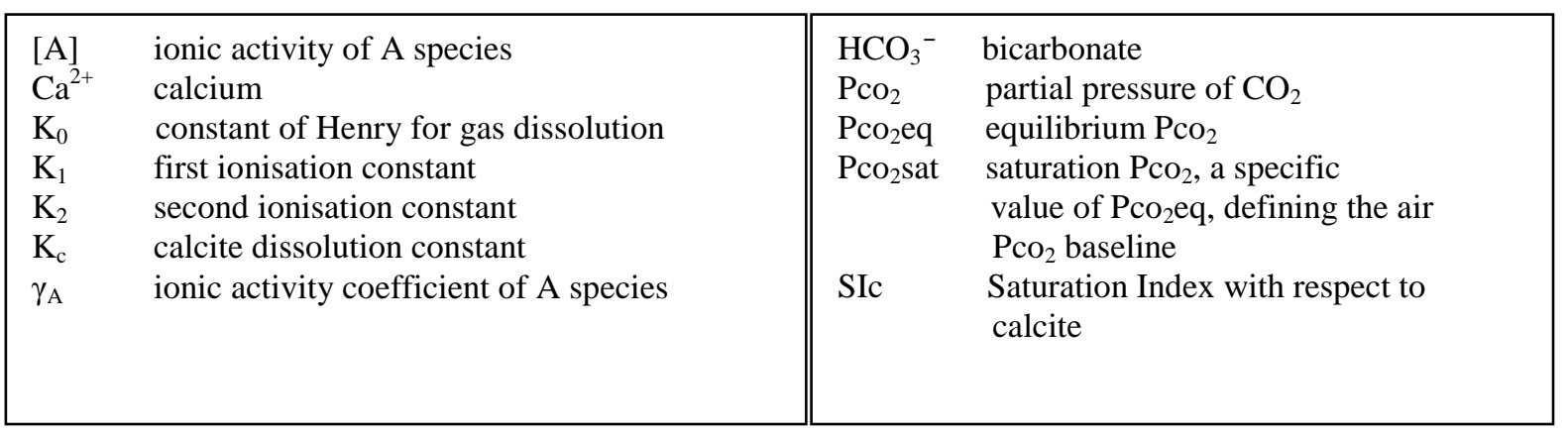

\section{Introduction}

In limestone aquifers, interactions between gas, water and rock are important processes triggering the aquifer behaviour. The $\mathrm{CO}_{2}$ present in the rock porosity (matrix and fractures) in the unsaturated zone dissolves in the water and increase its acidity. Commonly, the equilibrium $\mathrm{CO}_{2}$ partial pressure (named $\mathrm{PcO}_{2} \mathrm{eq}$ in this article) is used to take account of the dissolved $\mathrm{CO}_{2}$ and its consequences on the water total dissolved inorganic carbon. 
$\mathrm{PCO}_{2}$ eq had been studied to better understand the aquifer behaviour. The most common ways to use $\mathrm{PcO}_{2} \mathrm{eq}$ are: 1) in proposing an average characteristic value for water origin or flow condition, 2) in monitoring time series for temporal evolution, and 3) in assessing the degassing processes. For example, Thrailkill and Robl (1981) and Karimi et al. (2005) used $\mathrm{PcO}_{2} \mathrm{eq}$ to discriminate between quick and slow flows or open and closed conditions. Drake and Harmon (1973), Roberge (1989) and White (1997) characterised water type according to their origin: conduit, matrix (diffuse water), soil, run-off, river, tropical area and drip-water. Johnson et al. (2012) and Pasvanoghu and Gultekin (2012) showed the influence of deep sources of $\mathrm{CO}_{2}$ in the behaviour of aquifers.

Monitoring $\mathrm{Pco}_{2}$ eq evolution through time, in some researches (Vesper et al. 2004; Liu et al. 2007; Li et al. 2008; Zhao et al. 2010), estimated the contribution of different compartments during a flood event. Unger-Lindig et al. (2010) showed that evolution of $\mathrm{Pco}_{2} \mathrm{eq}$ can be used as an indicator of water quality following acidity neutralization activities. In the context of cave studies, Shuster and White (1972) and Troester and White (1984) made time series of $\mathrm{Pco}_{2}$ eq to estimate cave air $\mathrm{Pco}_{2}$ evolution along the year and Spötl et al. (2005) made comparisons between cave air $\mathrm{PcO}_{2}$ and $\mathrm{Pco}_{2}$ eq dissolved in water. Finally, effects of $\mathrm{CO}_{2}$ degassing processes were studied (Herman and Lorah 1986; Shuster and White 1971; Liu et al. 1995; Bono et al. 2001) on water flowing along surface streams after came to surface. Sometime, degassing can also be considered as a perturbation of the water sample. In this case then, the $\mathrm{Pco}_{2} \mathrm{eq}$ calculated from samples may not exactly represent the $\mathrm{PCO}_{2}$ eq of the water when it flows in the unsaturated zone.

Research studies were made to estimate the $\mathrm{Pco}_{2}$ eq of the water before the effect of the degassing. Some authors computed this effect with available software. For instance, Fairchild et al. (2000) used Mix4 program (Plummer et al. 1975) to estimate what was the $\mathrm{Pco}_{2}$ eq before degassing. Faimon et al. (2012a; 2012b) and Riechelmann et al. (2011) used PHREEQC software (Parkhurst 1995) to estimate the $\mathrm{Pco}_{2}$ eq before degassing, using measured bicarbonate and modelled $\mathrm{pH}$; adjusted until water reaches the saturation index with respect to calcite (named SIc). Another way to do this estimation is through analytical calculation based on calciumcarbonate equations (or carbonate equilibrium equations). Authors like White (1997), Tooth and Fairchild (2003), Vesper et al. (2004) and Mattey et al. (2010), calculated the air $\mathrm{Pco}_{2}$ that would justify the measured concentration in calcium.

However, it appears interesting to perform the calculation of the $\mathrm{PcO}_{2} \mathrm{eq}$ before degassing using bicarbonate instead of calcium. Indeed, bicarbonate is a central component in the relationship between air, water and rock, whereas, calcium ions are, rather, involved in water and rock interactions. Subsequently, Peyraube $e t$ 
al. (2012) proposed a calculation to estimate the $\mathrm{Pco}_{2} \mathrm{eq}$ that would justify the bicarbonate concentration, allowing an estimation of the $\mathrm{PCO}_{2} \mathrm{eq}$ before degassing and independently from $\mathrm{pH}$ measures. They presented the evolution of water during its flow in the unsaturated according to the different air $\mathrm{Pco}_{2}$ encountered. Yet, detailed information on the interpretations of water data $\left(\mathrm{PcO}_{2} \mathrm{eq}\right.$ and $\left.\mathrm{SIc}\right)$ to estimate air $\mathrm{PcO}_{2}$ values are found short in terms of presentation and full discussion.

In this line, this article focused on the use of $\mathrm{PcO}_{2} \mathrm{eq}$ and SIc in the context of limestone aquifers in an open system condition in order to: 1) estimate what was the $\mathrm{PCO}_{2}$ eq before degassing processes and 2) estimate the limits for the air $\mathrm{Pco}_{2}$ in contact with water. However, kinetic aspect of calco-carbonic relations and implications for speleothems growth are not discussed and may be found in the work of Dreybrodt et al. (1997). The main objective is to clearly expound the ways of interpretation of the $\mathrm{CO}_{2}$-SIc relationship and its representation in the $\left(-\log \left(\mathrm{PcO}_{2} \mathrm{eq}\right)\right.$; SIc) reference frame. These parameters might not be new but can still provide additional information on the air $\mathrm{PcO}_{2}$ in the unsaturated zone. An application is presented, using the measurements on water of three springs in Cussac site (France), to provide estimations of air $\mathrm{Pco}_{2}$ base line.

\section{Site background}

Cussac site is located in Southwest of France (Fig.1). It is a karstified aquifer composed of upper cretaceous calcareous sandstone. The width of the vadose zone can reach $70 \mathrm{~m}$ above the small saturated zone of about $10 \mathrm{~m}$. The saturated zone takes place above upper cretaceous marly limestone, characterized by lower permeability than the calcareous sandstone. Finally, a discontinuous, $\sim 20 \mathrm{~m}$ thick, blanket of clayey sands from Eocen-Oligocen can be seen at the top of the outcrops.

The climate is temperate with an average annual temperature of $13^{\circ} \mathrm{C}$, an average summer temperature between $22^{\circ} \mathrm{C}$ and $23^{\circ} \mathrm{C}$, and an average winter temperature between $2^{\circ} \mathrm{C}$ and $3^{\circ} \mathrm{C}$. The vegetation is composed of Oak and Chestnut trees. Average annual precipitation varies between 800 and 1000mm, and because of evapotranspiration, effective rainfall is computed ranging from 200 to $350 \mathrm{~mm}$ per year.

The site gives access to several springs; though, only three springs are presented in this article. The three springs take place in three compartment of the aquifer: Subcutaneous spring (156m.a.s.1.), a seasonal spring located in the upper part of the unsaturated zone; Farfal spring (110m.a.s.1.) in the unsaturated zone, the main outlet of the system; and the Gutter (95m.a.s.1.), an accumulation of water seeping from saturated zone. At Subcutaneous spring, the water flows in stress-released and aerated limestone before the sampling point. At Farfal spring, water surges in a small basin and is directly accessible. At the Gutter, the spring itself is not 
accessible and the water has a short flow on a cliff before the sampling point. Peyraube et al. 2012 presented a conceptual functioning scheme of the Cussac aquifer: rainwater flows through epikarst where it gains mineralization then it flows through the other parts of unsaturated zone where it degasses and precipitates calcite.

\section{Material and methods}

A bi-monthly monitoring for two years was conducted with water sampling and field measurements of conductivity, $\mathrm{pH}$ and temperature using WTW 340i probes. Measurements of bicarbonate concentration $\left(\mathrm{HCO}_{3}{ }^{-}\right)$using a Hach Lange field titrator was performed immediately on the site to avoid perturbation caused by late analysis. Water samples were filtered to $0.45 \mu \mathrm{m}$ and preserved at $4{ }^{\circ} \mathrm{C}$ in $60 \mathrm{ml} \mathrm{HDPE}$ flasks (one for anion, one for cation). The contents of the cation flasks were acidified with HCL. The ion concentrations $\left(\mathrm{Ca}^{2+}\right.$, $\mathrm{Na}^{+}, \mathrm{K}^{+}, \mathrm{Mg}^{2+}, \mathrm{Cl}^{-}, \mathrm{NO}_{3}^{-}$and $\mathrm{SO}_{4}{ }^{2-}$ ) were determined by Dionex ICS900 liquid chromatography. Table 1 gives the mean values of temperature, electrical conductivity, $\mathrm{pH}$ and major ions concentrations for the three springs.

\section{Discussion}

\section{1 $\mathrm{Pco}_{2}-$ SIc relationship}

In limestone environment, in the absence of dolostone, the groundwater chemistry is mainly driven by calcium and bicarbonate ions. Calcium-carbonate equations are governed by equilibrium constants dependent on the temperature. From these equations two parameters are calculated: equilibrium $\mathrm{CO}_{2}$ partial pressure $\left(\mathrm{PcO}_{2} \mathrm{eq}\right)$ and Saturation index with respect to calcite (SIc). $\mathrm{Pco}_{2}$ eq represents the $\mathrm{CO}_{2}$ partial pressure that would be in gas-liquid equilibrium with water at the moment of the measure. It is a transcription in terms of partial pressure of the $\mathrm{CO}_{2}$ dissolved in water (aqueous $\mathrm{CO}_{2}$ and $\mathrm{H}_{2} \mathrm{CO}_{3}$ ). SIc has been defined by Langelier (1936) as the ability of water to precipitate (for super saturated water with $\mathrm{SI}>0$ ) or dissolve calcium carbonate (for under saturated water with $\mathrm{SIc}<0)$.

From the expressions of these parameters, Peyraube et al. (2012) gave an expression of SIc dependent of $\mathrm{PcO}_{2} \mathrm{eq}$, bicarbonate activity and temperature (equations (1)):

(1) $\mathrm{SIc}=-1 \cdot \log \left(\mathrm{PCO}_{2} \mathrm{eq}\right)+3 \cdot \log \left[\mathrm{HCO}_{3}^{-}\right]+\log \left(\frac{K_{2}}{K_{0} \cdot K_{1} \cdot K_{c}} \cdot \frac{\gamma_{\mathrm{Ca}^{2+}}}{2 \cdot \gamma_{\mathrm{HCO}_{3}^{-}}}\right)$

$\mathrm{K}_{0}, \mathrm{~K}_{1}, \mathrm{~K}_{2}$ and $\mathrm{K}_{\mathrm{c}}$ are equilibrium constants dependent on the temperature calculated using the coefficients given by Plummer and Busenberg (1982) and the water temperature at the moment of sampling. The terms $\gamma_{\mathrm{ca}}$ and $\gamma_{\mathrm{HCO} 3}$ represent ionic activity coefficient (see nomenclature) and the term in square bracket is the 
activity of the ion. This expression is limited by some assumptions: 1) groundwater is electrically neutral, 2) mineralization is dominated by $\mathrm{Ca}^{2+}$ and $\mathrm{HCO}_{3}^{-}$in the absence of other species such as magnesium (no dolostone) or sulphates (no gypsum) in significant proportions, 3) $\mathrm{CaCO}_{3}$ precipitates only in calcite with no aragonite, and 4) $\mathrm{pH}$ is only driven by dissolved $\mathrm{CO}_{2}$.

Subsequently, for SIc equal to zero, the $\mathrm{Pco}_{2} \mathrm{eq}$ is called "water saturation $\mathrm{Pco}_{2}$ " and written $\mathrm{Pco}_{2} \mathrm{Sat}$ in equation (2):

(2) $\mathrm{PcO}_{2} \mathrm{Sat}=10^{\wedge}\left(3 \cdot \log \left[\mathrm{HCO}_{3}^{-}\right]+\log \left(\frac{K_{2}}{K_{0} \cdot K_{1} \cdot K_{c}} \cdot \frac{\gamma_{\mathrm{Ca}^{2+}}}{2 \cdot \gamma_{\mathrm{HCO}_{3}^{-}}}\right)\right)$

\section{2 conceptual uses of the projection in the $\left(-\log \left(\mathrm{Pco}_{2} \mathrm{eq}\right)\right.$; SIc $)$ reference frame}

The linear relationship between $-\log \left(\mathrm{PcO}_{2} \mathrm{eq}\right)$ and SIc described in equation (1) is represented by the straight black line with a slope of 1 in the $\left(-\log \left(\mathrm{PcO}_{2} \mathrm{eq}\right)\right.$; SIc) graph presented in Fig.2. The vertical axis differentiates super saturated water, under saturated water and saturated water for SIc equal to zero with a tolerance of \pm 0.1 . Above the horizontal axis corresponding to $-\mathrm{Log}\left(\mathrm{Pco}_{2} \mathrm{eq}\right)$, an indicative scale of $\mathrm{PcO}_{2} \mathrm{eq}$ expressed as a percentage is added to help the interpretation $(10000 \mathrm{ppm}=1 \%)$. An indicative $\mathrm{HCO}_{3}{ }^{-}$scale in $\mathrm{mg} / \mathrm{l}$, computed for a temperature of $13^{\circ} \mathrm{C}$, is displayed on the graph. In Fig.2, an example is computed for $\mathrm{HCO}_{3}{ }^{-}$equal to $220 \mathrm{mg} / \mathrm{L}$ at $13^{\circ} \mathrm{C}$ at various $\mathrm{Pco}_{2} \mathrm{eq}$ drawing to the black line. The specific value of $\mathrm{PcO}_{2} \mathrm{eq}$

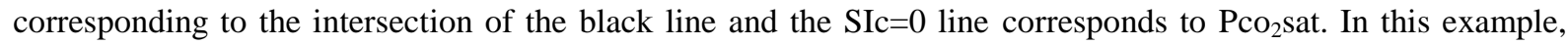
$\mathrm{PcO}_{2}$ sat is equal to $0.6 \%$, calculated from equation (2). For this particular value, the water is in equilibrium with

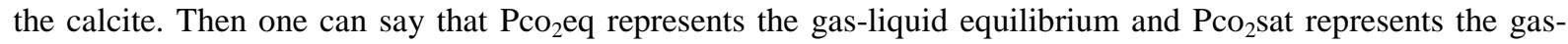
liquid-solid equilibrium.

During the transit of the water in the unsaturated zone, $\mathrm{Pco}_{2} \mathrm{eq}$ and $\mathrm{HCO}_{3}{ }^{-}$will vary through gas dissolution (gassing) and degassing processes and through calcite dissolution and precipitation processes. The variations of $\mathrm{PcO}_{2} \mathrm{eq}$ and $\mathrm{HCO}_{3}^{-}$can be simultaneous, however, gassing and degassing are rapid processes compared to dissolution and precipitation in non-turbulent flow (Ford and Williams 2007). Then, to simplify the concept of the processes, any variation of $\mathrm{Pco}_{2} \mathrm{eq}$ and $\mathrm{HCO}_{3}{ }^{-}$is divided into a succession of two consecutive steps where one parameter varies while the other remains constant. In that case, the arrows displayed in the Fig.2 present the possible changes of water chemical characteristics for a constant water temperature. These changes correspond to: variation of $\mathrm{Pco}_{2}$ eq caused by gassing and degassing (arrow no.1) or variation in $\mathrm{HCO}_{3}^{-}$ concentration caused by dissolution and precipitation of calcite (arrow no.2). 
Displaying the data on the $\left(-\log \left(\mathrm{Pco}_{2} \mathrm{eq}\right)\right.$; SIc $)$ reference frame is a useful technique to display the variability of water chemistry (White 1997; Leybourn et al. 2009) or to assess the origin of water (Roberge 1989). This representation can also help to better understand the processes that happened during the transit of the water in the unsaturated zone, in the saturated zone and even at the sampling point. In Fig.3, several illustrations of the uses of this reference frame were presented. The proposed theoretical examples are not modelled data but rather arbitrary values of $\mathrm{Pco}_{2}$, temperature and $\mathrm{HCO}_{3}{ }^{-}$chosen to illustrate the use of the $\mathrm{Pco}_{2}$-Isc relationship.

Fig.3.a presents the perturbation caused by site effect. The term "site effect" embraces the alterations and influences on the quality of the measure caused by configuration and accessibility of the sampling point. A simple field example is an inaccessible spring where water can be sampled only after a short turbulent flow at the surface. In this case, the measure $\mathrm{Pco}_{2} \mathrm{eq}$ is not anymore representative as the water undergone degassing before sampling. In Fig.3.a, the theoretical example talks about a water in gas-liquid equilibrium inside the unsaturated zone, with a $\mathrm{PcO}_{2} \mathrm{eq}$ of $5 \%$ (represented in the point "b"). This water reaches the surface and undergoes degassing and, at the moment of sampling, $\mathrm{Pco}_{2} \mathrm{eq}$ is measured at $0.1 \%$. Despite degassing, this kind of water still provides information on the air $\mathrm{PcO}_{2}$ of the unsaturated zone. $\mathrm{Pco}_{2}$ sat presented in point "a" is equal to $1 \%$. It represents a minimum limit of the possible air $\mathrm{PcO}_{2}$ values of the unsaturated zone. Indeed, the starting $\mathrm{PcO}_{2} \mathrm{eq}$ of $5 \%$ is higher than $\mathrm{Pco}_{2} \mathrm{sat}$ and the water in "b" is under-saturated with respect to calcite. If the water would have stayed in the unsaturated zone, dissolution processes could have occurred, and a new equilibrium between gas, liquid and solid would have been reached in "c" for a higher $\mathrm{HCO}_{3}{ }^{-}$concentration.

Fig.3.b shows the theoretical example of water flowing through two compartments characterised by two different air $\mathrm{PcO}_{2}$ in the unsaturated zone and, finally, arriving at the earths surface. Thus, these parts are mentioned as "second to last compartment", and "last compartment" and, finally, "external atmosphere". In this theoretical example, let's imagine an air $\mathrm{Pco}_{2}$ higher in "the second to last compartment" than in "the last compartment". This leads the water to undergo degassing inside the unsaturated zone when it arrives in the last compartment. Then, subsequently to the degassing, the water undergo calcite precipitation. Afterwards, the water reaches the surface and can be sampled and $\mathrm{Pco}_{2} \mathrm{eq}$ is measured.

Air $\mathrm{Pco}_{2}$ in the second to last compartment is supposed to be unknown and written "d?". Although, to draw the figure, a value of $5 \%$ for air $\mathrm{Pco}_{2}$ is chosen. In the last compartment, the water degasses from value "d?" to the measured $\mathrm{Pco}_{2} \mathrm{eq}(0.1 \%)$. The measured $\mathrm{Pco}_{2} \mathrm{eq}$ may not represent the last compartment air $\mathrm{Pco}_{2}$, but $\mathrm{PcO}_{2}$ sat can provide information on it. The $\mathrm{Pco}_{2} \mathrm{sat}$ in point "a" $(0.3 \%)$ is the maximum limit of possible air $\mathrm{Pco}_{2}$ that forced the water to degas and precipitate in the last compartment. Air $\mathrm{Pco}_{2}$ in the last compartment may be 
lower than measured $\mathrm{Pco}_{2} \mathrm{eq}(0.1 \%)$. In this case and if the water would have stayed in the last compartment in the unsaturated zone, the water would have continue to degas and precipitate until it would have reached an equilibrium with respect to calcite.

$\mathrm{PCO}_{2} \mathrm{Sat}$ is a particular value of $\mathrm{PcO}_{2} \mathrm{eq}$ for SIc equal to zero, and can be accepted as a footprint of the air $\mathrm{PcO}_{2}$ with which water has interacted in the unsaturated zone. $\mathrm{PcO}_{2} \mathrm{sat}$ is a maximum or a minimum value of the air $\mathrm{PcO}_{2}$ in the unsaturated zone and the interpretation depends on the behaviour of the water before sampling: degassing only or degassing and precipitation.

In a given spring, $\mathrm{PcO}_{2} \mathrm{eq}$ and $\mathrm{PcO}_{2} \mathrm{sat}$ (calculated from $\mathrm{HCO}_{3}{ }^{-}$concentration) may vary over the years. Nonetheless, the natural yearly variations of $\mathrm{PcO}_{2} \mathrm{eq}$ and $\mathrm{PcO}_{2} \mathrm{sat}$ ranges between usual values characterising the spring. Then, on a $\left(-\log \left(\mathrm{PcO}_{2} \mathrm{eq}\right)\right.$; SIc) reference frame in figures 2.c and 2.d, the samples are gathered within a zone represented by the square area that takes account of the variability of the $\mathrm{Pco}_{2} \mathrm{eq}$ and the $\mathrm{HCO}_{3}{ }^{-}$ concentration. Field cases of this gathering of samples are presented in Fig. 3 from Cussac site measures.

Fig.3.c and 3.d specially talks about the consequences of an important increase of $\mathrm{PcO}_{2}$ in the air of the unsaturated zone. Discussing the causes of the variation is not the aim of this article. To give an example, one of the causes can be a $\mathrm{CO}_{2}$ leakage from geological storage. Limestone would probably not be used as host layer for geological $\mathrm{CO}_{2}$ storage, however, limestone can be found above the host layer of geological $\mathrm{CO}_{2}$ storage and be affected by leakage as $\mathrm{CO}_{2}$ gas will move toward surface.

Fig.3.c shows the theoretical example of an increased of air $\mathrm{Pco}_{2}$ on a water that does not interact for a long time with this abnormal high air $\mathrm{PcO}_{2}$. It can be possible if the water flows quickly in the unsaturated zone and reaches the surface where it is sampled. Then, gas-liquid interaction may occur and lead to an increase of $\mathrm{PcO}_{2}$ eq. Yet, the interaction time is too short to lead to noticeable change in $\mathrm{HCO}_{3}{ }^{-}$concentration and $\mathrm{PcO}_{2} \mathrm{Sat}$ remain unchanged. In the example, $\mathrm{Pco}_{2}$ eq increases from a common value in point "a" to the measured value. The water becomes more under saturated with respect to calcite (SIc is highly negative).

Fig.3.d shows the theoretical example of an increase of air $\mathrm{Pco}_{2}$ on water with a slow flow that interacts for a long time with this abnormal high air $\mathrm{Pco}_{2}$. Then, gas-liquid-solid interaction may occur, leading to an increase of $\mathrm{PcO}_{2} \mathrm{eq}$ and, in addition, carbonate dissolution may occur leading to an increase of $\mathrm{PcO}_{2} \mathrm{Sat}$ The example presents water with a given $\mathrm{HCO}_{3}{ }^{-}$concentration and a $\mathrm{Pco}_{2} \mathrm{eq}$ of $0.5 \%$ in the point "a". Then, let's imagine that the water is in contact with an air $\mathrm{Pco}_{2}$ of $3.1 \%$. Subsequently, there is gas dissolution and $\mathrm{PcO}_{2} \mathrm{eq}$ increases to reach $3.1 \%$. As the water remains in contact with the limestone, carbonate dissolution occurs until equilibrium with respect to calcite is reached $(\mathrm{SIc}=0) . \mathrm{PcO}_{2} \mathrm{Sat}$ increases toward a new value equal to $3.1 \%$, the 
same as air $\mathrm{PcO}_{2}$ and $\mathrm{Pco}_{2}$ eq. However, water can be sampled at any moment of this process. Then, the Fig.3.d shows several possible samples scattered along a vertical line with an abscissa corresponding to a $\mathrm{PcO}_{2} \mathrm{eq}$ of $3.1 \% . \mathrm{PCO}_{2}$ sat of the samples can have any value between 0.5 and $3.1 \%$.

An important increase of $\mathrm{PcO}_{2}$ in the air of the unsaturated zone can be detected by $\mathrm{PcO}_{2} \mathrm{eq}$ or $\mathrm{PcO}_{2} \mathrm{Sat}$ according to the behaviour of the water: quick flow or slow flow. However, limitations exist as the method works only in limestone as water mineralization have to be dominated by $\mathrm{Ca}^{2+}$ and $\mathrm{HCO}_{3}{ }^{-}$. In addition, $\mathrm{PcO}_{2} \mathrm{eq}$ can be affected by degassing occurring before sampling as described in Fig.3.a. Then, no variations are noticeable. $\mathrm{PcO}_{2} \mathrm{sat}$ is not affected by degassing and represents an integrative measure. Indeed, $\mathrm{PcO}_{2} \mathrm{Sat}_{\text {will }}$ increase if there an increase of air $\mathrm{Pco}_{2}$ occurs in whichever part of the whole volume of the unsaturated zone that contributes to drain water towards the point where water is sampled. Nonetheless, the interaction time between water and limestone has to be sufficient to lead to noticeable carbonate dissolution. As described in Fig.3.b, another limitation in the use of $\mathrm{PcO}_{2} \mathrm{sat}$ is that no precipitation should occurs in a compartment of the unsaturated zone following the last increase of $\mathrm{PcO}_{2}$ sat.

\section{Application}

In Cussac site, $\mathrm{PcO}_{2} \mathrm{eq}$ and $\mathrm{Pco}_{2}$ sat are calculated for Subcutaneous spring $(\mathrm{n}=7)$, Farfal spring $(\mathrm{n}=56)$ and for the Gutter $(\mathrm{n}=26)$. The aim of the present article is to focus on the uses of $\mathrm{Pco}_{2} \mathrm{eq}$ and $\mathrm{Pco}_{2} \mathrm{Sat}$ to estimate air $\mathrm{PCO}_{2}$ baseline line the unsaturated zone. A detailed review of the results from the measurements on these springs is available in the work of Peyraube et al. 2012. Table 1 gives the mean values of the measured parameters. Water chemistry is mostly represented by calcium and bicarbonate. In the absence of dolostone, magnesium concentration remains low. Fig.4 presents the projections of the samples from the 3 springs in the $\left(-\mathrm{Log}\left(\mathrm{PcO}_{2} \mathrm{eq}\right)\right.$; SIc $)$ reference frame. For each spring, a model was constructed. This model (see Fig.4) is not a linear regression but a constrained straight line with a slope of 1 . For each sample belonging to the same spring, a modelled SIc is calculated using the sample's $\mathrm{Pco}_{2} \mathrm{eq}$ and the average SIc and $\mathrm{Log}\left(\mathrm{PcO}_{2} \mathrm{eq}\right)$ of the considered spring (equation (3))

(3) $\operatorname{SIc}_{\text {model }}=1 \cdot-\log \left(\mathrm{PCO}_{2} e q\right)+\left(\overline{\mathrm{SIc}}-\overline{\log \left(\mathrm{PCO}_{2} e q\right)}\right)$

Equation (3) is the expression of a straight line $(y=a * x+b)$ where the term "b" directly comes from the equation (2) applied to the gravity centre of the samples in $\left(-\log \left(\mathrm{Pco}_{2} \mathrm{eq}\right)\right.$; SIc ) reference frame. The models help to define an average $\mathrm{Pco}_{2}$ sat that characterises the spring: $4.0 \pm 0.7 \%$ at subcutaneous spring, $2.5 \pm 0.1 \%$ at Farfal spring and $1.8 \pm 0.1 \%$ at the Gutter. 
Subcutaneous spring and the Gutter are good examples of the degassing presented in Fig.3.a. The configuration of the sites, or "site effect", leads to degassing before the sampling. Then, the values of $\mathrm{PcO}_{2} \mathrm{eq}$ from this water are not representatives of the air $\mathrm{PcO}_{2}$ in the unsaturated zone. Otherwise, Farfal spring and the Gutter are good examples of the processes presented in Fig.3.b. Besides, Farfal spring and the Gutter are good illustration of the gathering of the samples in a square limited by usual values characterising the spring.

The interpretations of $\mathrm{PCO}_{2}$ sat from the three springs follow the examples of Fig.3. Epikarst spring $\mathrm{PcO}_{2}$ sat is a footprint of what was the $\mathrm{PcO}_{2}$ eq before degassing (c.f. Fig.3.a); it represents the minimum value of air $\mathrm{PcO}_{2}$ in the upper part of the unsaturated zone. Farfal spring $\mathrm{PcO}_{2} \mathrm{Sat}_{\text {a }}$ a footprint of what was the air $\mathrm{PcO}_{2}$ in the part of the unsaturated zone where the water degassed and precipitate calcite (c.f. Fig.3.b). It represents the maximum value of the air $\mathrm{PcO}_{2}$, present in this area, that leads to degassing and precipitation towards a new equilibrium with respect to calcite, whether this equilibrium was reached or not. The Gutter $\mathrm{Pco}_{2} \mathrm{sat}_{\text {is }}$ a footprint of what was the $\mathrm{Pco}_{2}$ eq before degassing (Fig.3.a) and it represent the maximum value of the air $\mathrm{PcO}_{2}$ (Fig.3.b) in this part of the unsaturated zone at the limit with the saturated zone.

Furthermore, times series of the maximum and minimum values of the air $\mathrm{Pco}_{2}$ baseline can be proposed in Fig.5. From Subcutaneous spring, one estimates the air $\mathrm{Pco}_{2}$ in upper part of the unsaturated zone higher than to $4.0 \%$ on average. This estimation of the lower limit is in accordance with estimation of air $\mathrm{PcO}_{2}$ proposed by Peyraube et al. 2013 using isotopes measures and ranging from $6.2 \%$ to $11.5 \%$. From Farfal spring, the higher limit of air $\mathrm{Pco}_{2}$ ranges from $2.2 \%$ to $2.8 \%$ along the year. These stable values can be taken as an estimation of the air $\mathrm{Pco}_{2}$ base line in the unsaturated zone. Then, from the Gutter one can define another air $\mathrm{PcO}_{2}$ baseline corresponding to another part of the unsaturated zone closer to the limit with the saturated zone. This second baseline ranges from $1.4 \%$ to $2.0 \%$ and appears also very stable along the year. On Cussac site, the decrease of the values of the estimated base lines from upper part to lower part of the unsaturated zone shows that the air $\mathrm{Pco}_{2}$ value is inversely proportional with the distance from the surface. This leads for a $\mathrm{CO}_{2}$ originating from surface with a production from vegetation roots and soil organic matter degradation.

\section{Conclusion}

Natural $\mathrm{CO}_{2}$ baseline of unsaturated zone can be estimated with water measurements and new interpretations of calco-carbonic equations. This estimation relies on saturation $\mathrm{PcO}_{2}\left(\mathrm{Pco}_{2} \mathrm{sat}\right)$ which is a footprint of the air $\mathrm{PcO}_{2}$ in the unsaturated zone of limestone aquifer with which water has interacted. This study showed that in one hand, $\mathrm{Pco}_{2}$ sat can correspond to the maximum value of air $\mathrm{Pco}_{2}$ encountered in the 
unsaturated zone that justify the bicarbonate concentration. On the other hand, $\mathrm{Pco}_{2} \mathrm{sat}$ can correspond to the maximum air $\mathrm{PcO}_{2}$ that led the water to degas $\mathrm{CO}_{2}$ and precipitate carbonate. Applied on Cussac site in carbonated system, the method gives good and sound results for natural $\mathrm{CO}_{2}$ estimation.

\section{Acknowledgment}

The authors wish to thank the DREAL Aquitaine and the DRAC Aquitaine for their funding and support.

Financial support was also given by the European project FEDER.

\section{References}

Bono P, Dreybrodt W, Errcole S, Percopo C, Vosbeck K (2001) Inorganic calcite precipitation in tartare karstic spring (Lazio, central Italy) : field measurement and theoretical prediction on depositional rates. Environmental Geology 41:305-313.

Drake J, Harmon RS (1973) Hydrochemival Environments of Carbonate Terrains. Water resources research 9: 949-957.

Dreybrodt, W, Einsenlohr L, Madry B, Ringer S (1997) Precipitation kinetics ofcalcite in the system $\mathrm{CaCO}_{3^{-}}$ $\mathrm{H}_{2} \mathrm{O}-\mathrm{CO}_{2}$ : the conversion to $\mathrm{CO}_{2}$ by the slowprocess $\mathrm{H}++\mathrm{HCO}_{3}{ }^{-} \rightarrow \mathrm{CO}_{2}+\mathrm{H}_{2} \mathrm{O}$ as a limiting steps. Geochimica et Cosmochimica Acta 61:3897-3904.

Faimon J, Ličbinská M, Zajíček P (2012a) Relationship between carbon dioxide in Balcarka Cave and adjacent soils in the Moravian Karst region of the Czech Republic. International Journal of Speleology 41:17-28.

Faimon J, Ličbinská M, Zajíček P, Sracek O (2012b) Partial pressures of $\mathrm{co}_{2}$ in epikarstic zone deduced from hydrogeochemistry of permanent drips, the moravian karst, czech republic. Acta Carsologica 41:47-57.

Fairchild IJ, Borsato A, Tooth AF, Frisia S, Hawkesworth CJ, Huang Y, McDermott F, Spiro B (2000) Controls on trace element $\mathrm{Sr}-\mathrm{Mg}$ compositions of carbonate cave waters: implications for speleothem climatic records. Chemical Geology 166:255-269.

Ford D, Williams P (2007) Karst hydrogeology and geomorphology. Wiley, 7th edition, ISBN : 978-0-47084997-2, 562p.

Herman J, Lorah M (1986) CO2 outgassing and calcite precipitation in falling spring creek, Virginia, USA. Chemical Geology 62:251-262. 
Johnson RH, DeWitt E, Arnold LR (2012) Using hydrogeology to identify the source of groundwater to Montezuma Well, a natural spring in Central Arizona, USA: part 1. Environmental Earth Sciences 67: 1821-1835.

Karimi H, Raesi E, Bakalowicz M (2005) Characterising the main karst aquifers of the Alvand basin, northwest of Zagros, Iran, by a hydrogeochemical approach. Hydrogeology Journal 13:787-799.

Langelier WF (1936) The analystical control of anti-corrosion water treatment. Journal of American Waterworks Association 28:1500-1521.

Leybourne ML, Betcher RN, McRitchie WD, Kaszycki CA, Boyle DR (2009) Geochemistry and stable Geochemistry and stable isotopic composition of tufa waters and precipitates from the Interlake Region, Manitoba, Canada: Constraints on groundwater origin, calcitization, and tufa formation. Chemical Geology 260:221-233.

Li Q, Sun H, Han J, Liu Z, Yu L (2008) High-resolution study on the hydrochemical variations caused by the dilution of precipitation in the epikarst spring: an example spring of Landiantang at Nongla, Mashan, China. Environ Geology 54:347-354.

Liu Z, Li Q, Sun H, Wang J (2007) Seasonal, diurnal and storm-scale hydrochemical variations of typical springs in subtropical karst areas of SW China : Soil $\mathrm{CO}_{2}$ and dilution effects. Journal of Hydrology 337:207-223.

Liu Z, Svensson U, Dreybrodt W, Daoxian Y, Buhmann D (1995) Hydrodynamic control of inorganic calcite precipitation in Huanglong Ravine, China: Field measurements and theoretical prediction of deposition rates. Geochimica et Cosmochimica Acta 59:3087-3097.

Mattey DP, Fairchild IJ, Atkinson TC, Latin JP, Ainsworth M, Durell R (2010) Seasonal microclimate control of calcite fabrics, stable isotopes and trace elements in modern speleothem from St Michaels cave, Gibraltar. Geological Society of London special volume 336:323-344.

Parkhurst DL (1995) User's guide to PHREEQC A computer program for speciation, reaction-path, advectivetransport, and inverse geochemical calculations. U.S. Geological Survey Water-Resources Investigations Report 95-4227.

Pasvanoglu S, Gultekin F (2012) Hydrogeochemical study of the Terme and Karakurt thermal and mineralized waters from Kirsehir Area, central Turkey. Environmental Earth Sciences 66:169-182.

Peyraube N, Lastennet R, Denis A (2012) Geochemical evolution of groundwater in the unsaturated zone of a karstic massif, using the $\mathrm{Pco}_{2}$-SIc relationship. Journal of Hydrology 430:13-24. 
Peyraube N, Lastennet R, Denis A, Malaurent P (2013) Estimation of epikarst air $\mathrm{Pco}_{2}$ using measurements of water $\mathrm{D}^{13} \mathrm{C}_{\mathrm{TDIC}}$, cave air $\mathrm{Pco}_{2}$ and $\mathrm{D}^{13} \mathrm{CcO}_{2}$. Geochimica et Cosmochimica Acta 118:1-17.

Plummer LN, Parkhurst DL, Kosiur DR (1975) MIX2, a computer program for modeling chemical reactions in natural waters. U.S. Geological Survey Water-Resources Investigations Report 61.

Plummer LN, Busenberg E (1982) the solubility of calcite, argonite and waterite in $\mathrm{CO}_{2}-\mathrm{H}_{2} \mathrm{O}$ solutions between 0 and $90^{\circ} \mathrm{C}$, and evaluation of the aqueous model of the system $\mathrm{CaCO}_{3}-\mathrm{CO}_{2}-\mathrm{H}_{2} \mathrm{O}$. Geochimica et Cosmochimica Acta 46:1011-1040.

Riechelmann DFC, Schröder-Ritzrau A, Scholz D, Fohlmeister J, Spötl C, Richter DK, Mangini A (2011) Monitoring Bunker Cave (NW Germany): A prerequisite to interpret geochemical proxy data of speleothems from this site. Journal of Hydrology 409:682-695.

Roberge J (1989) Géomorphologie du karst de la Haute-Saumons, île d'Anticosti, Quebec. thesis, Université McMaster.

Shuster ET, White WB (1972) Source areas and climatic effects in carbonate groundwaters determinated by saturation indices and carbon dioxide pressure. Water resources research 8:1067-1073.

Shuster ET, White WB (1971) Seasonal fluctuations in the chemistry of limestone spring: a possible means for characterizing carbonate aquifers. Journal of Hydrology 14:93-128.

Spötl C, Fairchild IJ, Tooth AF (2005) Cave air control on dripwater geochemistry, Obir Caves (Austria): Implications for speleothem deposition in dynamically ventilated caves. Geochimica et Cosmochimica Acta 69:2451-2468.

Thrailkill J, Robl TL (1981) Carbonate geochemistry of vadose water recharging limestone aquifers. Journal of Hydrology 54:195-208.

Tooth A, Fairchild IJ (2003) Soil and karst aquifer hydrological controls on the geochemical evolution of speleothem-forming drip water, Crag Cave, southwest Ireland. Journal of Hydrology 273:51-68.

Troester JW, White WB (1984) Seasonal fluctuations in the dioxide partial pressure in a cave atmosphère. Water resources research 20:53-156.

Unger-Lindig Y, Merkel B, Schipek M (2010) Carbon dioxide treatment of low density sludge: a new remediation strategy for acidic mining lakes?. Environmental Earth Sciences 60:1711-1722.

Vesper DJ, White WB (2004) Storm pulse chemographs of saturation index and carbon dioxide pressure: implications for shifting recharge sources during storm events in the karst aquifer at Fort Campbell, Kentucky/Tennessee, USA. Hydrogeology Journal 12:135-143. 
White WB (1997) Thermodynamic equilibrium, kinetics, activation barriers, and reaction mechanisms for chemical reactions in Karst Terrains. Environmental Geology 30:46-58.

Zhao M, Zeng C, Liu Z, Wang S (2010) Effect of different land use/land cover on karst hydrogeochemistry: a paired catchments study of Chenqi and Dengzhanhe, Punding, Guizhou, SW China. Journal of Hydrology 388:121-130.

\section{Figures}

\section{Tertiary sandy-clayey deposit}

Campanian calcareous sandstone

D. Campanian marly limestone

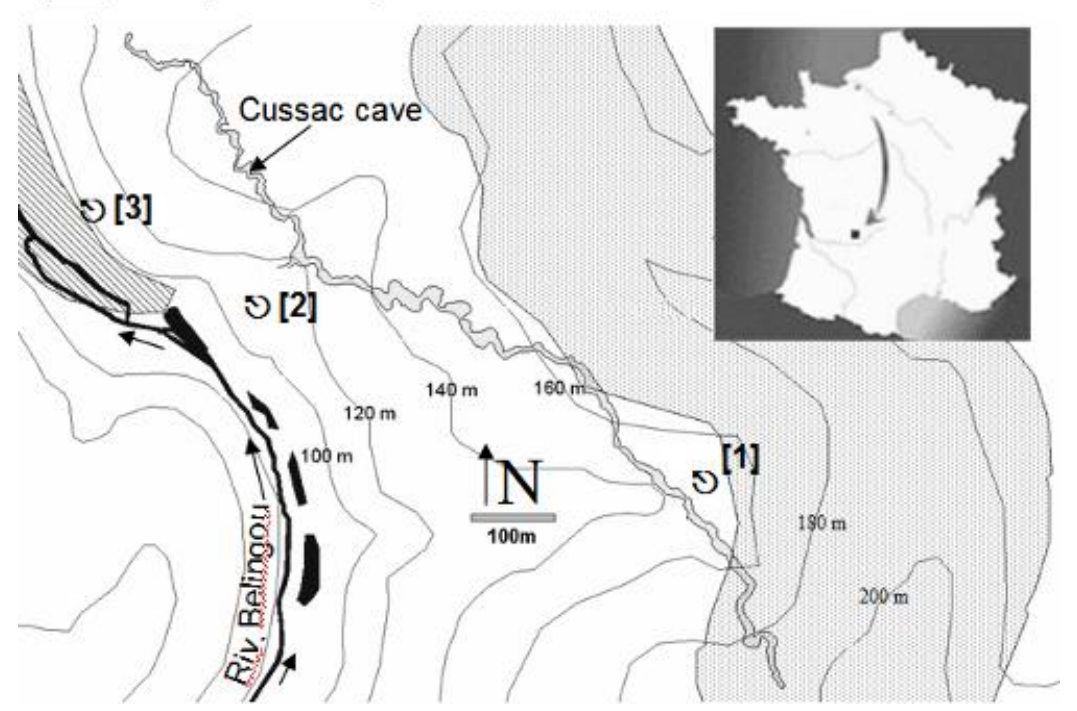

Fig.1 Location and simplified geological context of Cussac site with three of the main springs: [1] Subcutaneous spring, [2] Farfal spring and [3] the Gutter for seepage water 


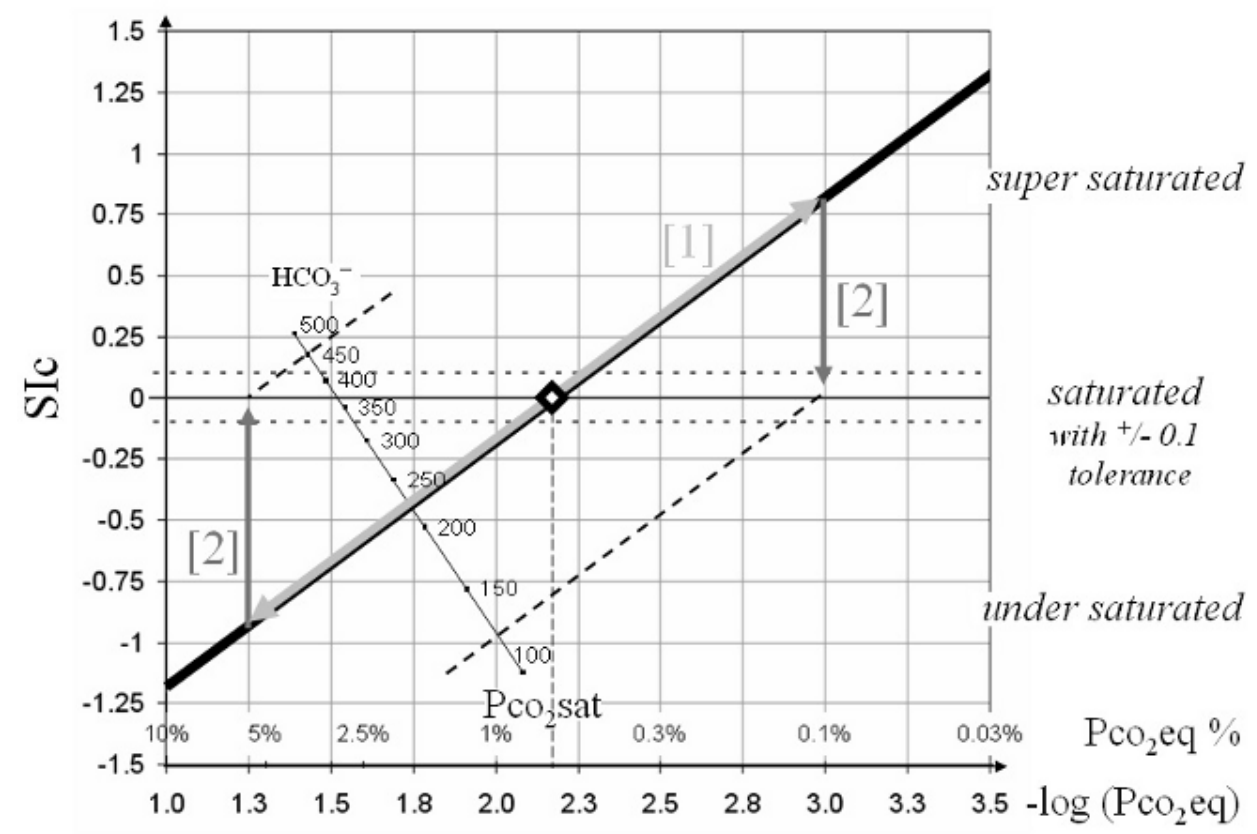

Fig.2 (-log $\left(\mathrm{PcO}_{2} \mathrm{eq}\right)$; SIc) reference frame. A scale for $\mathrm{PcO}_{2} \mathrm{eq}$ (in percent) is added above horizontal axis; a scale for $\mathrm{HCO}_{3}^{-}$concentration in $\mathrm{mg} / \mathrm{l}$ at $13^{\circ} \mathrm{C}$ is added. Black line represents a constant bicarbonate concentration. Light-grey arrow [1] corresponds to gassing and degassing for constant $\mathrm{HCO}_{3}{ }^{-}$concentration, grey arrow [2] corresponds to calcite precipitation or dissolution for constant $\mathrm{PcO}_{2} \mathrm{eq}$
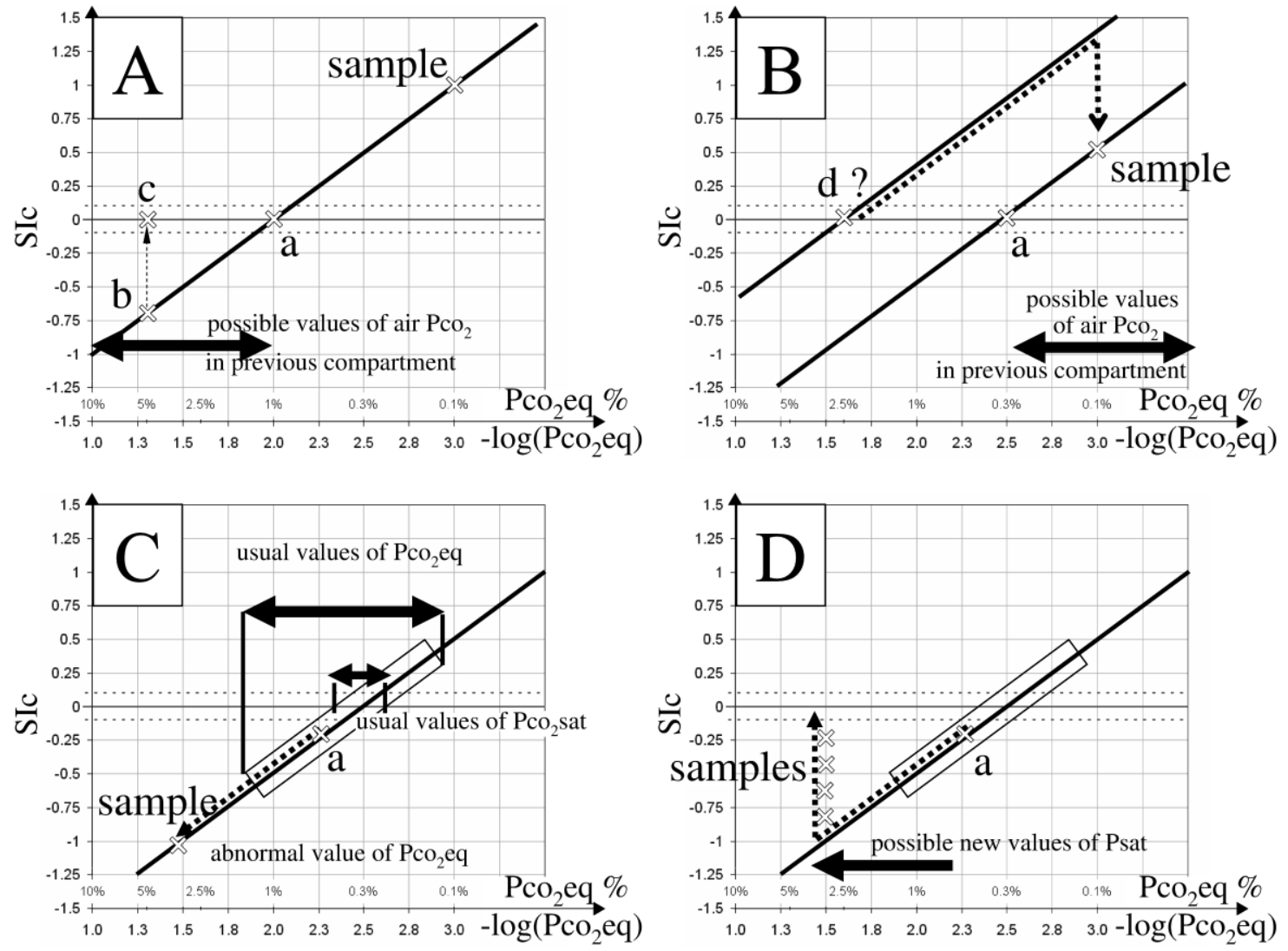
Fig.3 (a) and (b) quarters illustrate the meaning of $\mathrm{Pco}_{2} \mathrm{sat}$ as minimum and maximum for air $\mathrm{Pco}_{2}$ estimation. (a) quarter corresponds to water undergoing degassing only from high value of air $\mathrm{Pco}_{2}$ in " $\mathrm{b}$ " to $\mathrm{Pco}_{2} \mathrm{eq}$ of the sample point; $\mathrm{Pco}_{2}$ sat calculated in "a" is the minimum limit of possible air $\mathrm{Pco}_{2}$ in previous compartment, $\mathrm{PcO}_{2} \mathrm{Sat}=1 \%<5 \%$ in "b". (b) quarter corresponds to water undergoing degassing and calcite precipitation from unknown value of air $\mathrm{Pco}_{2}$ in "d" to $\mathrm{PcO}_{2}$ eq of the sample point; $\mathrm{Pco}_{2}$ sat calculated in "a" is the maximum limit of possible air $\mathrm{PcO}_{2}$ that led to degassing-precipitation in former compartment. (c) and (d) quarters illustrate the consequences of air $\mathrm{PcO}_{2}$ increase in unsaturated zone on spring water; usual values of $\mathrm{PcO}_{2} \mathrm{eq}$ and $\mathrm{PcO}_{2} \mathrm{Sat}$ of the water are within the symbolised square area. (c) quarter corresponds to the first consequences of air $\mathrm{PcO}_{2}$ increase leading to an increase of sample $\mathrm{Pco}_{2} \mathrm{eq}$, without carbonate dissolution $\left(\mathrm{Pco}_{2}\right.$ sat unchanged). (d) quarter corresponds to long term consequences of air $\mathrm{Pco}_{2}$ increase with carbonate dissolution and new values of $\mathrm{PcO}_{2}$ sat; an increase of $\mathrm{PcO}_{2}$ sat is an evidence of long term air $\mathrm{Pco}_{2}$ increase and water sample may be measured at different SIc values for a given $\mathrm{Pco}_{2} \mathrm{eq}$.

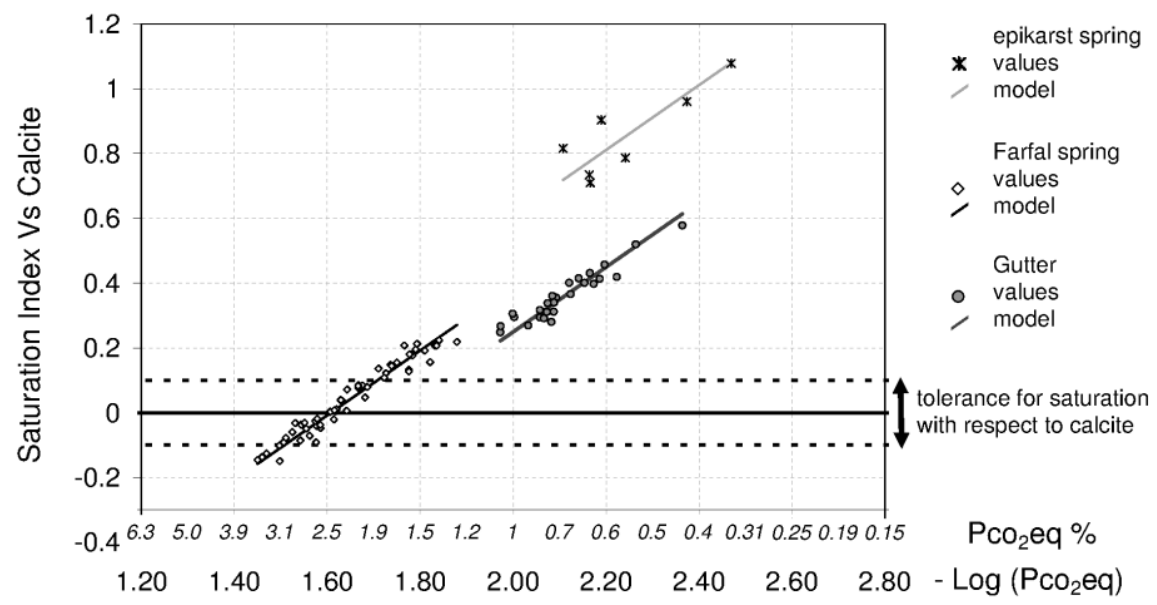

Fig.4 Projection of sample from Subcutaneous spring, Farfal spring and the Gutter in the $(-\log ($ Pco2eq) ; SIc) reference frame, models are calculated from equation (3) for a temperature of $13^{\circ} \mathrm{C}$ corresponding to the average temperature of the samples. 


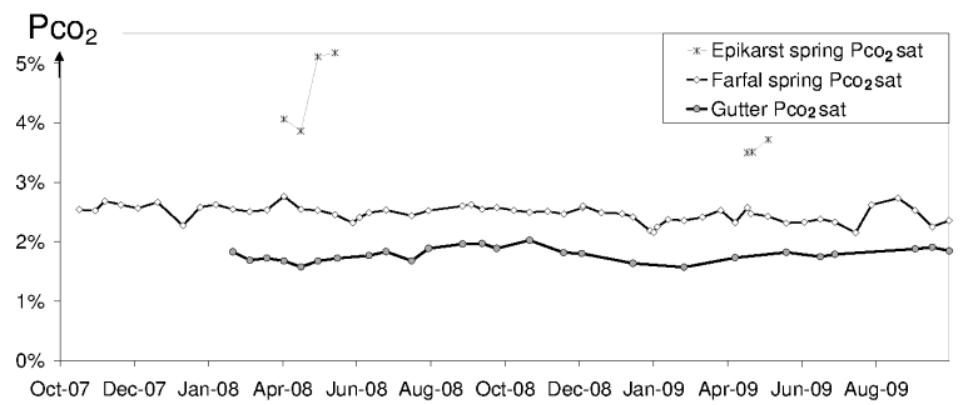

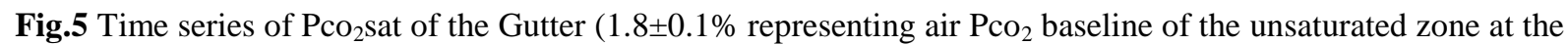
limit with the saturated zone; $\mathrm{PcO}_{2}$ sat of the Farfal spring $\left(, 2.5 \pm 0.1 \%\right.$ representing the unsaturated zone air $\mathrm{PcO}_{2}$ baseline; $\mathrm{PcO}_{2} \mathrm{Sat}$ of the Subcutaneous spring $(4.0 \pm 0.7 \%)$ cannot be considered as a base line but gives indications on air Pco2 in this part of the unsaturated zone

\begin{tabular}{|l|c|c|c|c|c|c|c|c|c|c|c|c|}
\hline & $\begin{array}{c}\text { Temp. } \\
{ }^{\circ} \mathrm{C}\end{array}$ & $\begin{array}{c}\mathrm{EC} \\
\mu \mathrm{S} / \mathrm{cm}\end{array}$ & $\mathrm{pH}$ & $\mathrm{HCO}_{3}^{-}$ & $\mathrm{Ca}^{2+}$ & $\mathrm{Na}^{2+}$ & $\mathrm{K}^{+}$ & $\mathrm{Mg}^{2+}$ & $\mathrm{Cl}^{-}$ & $\mathrm{NO}_{3}^{-}$ & $\mathrm{SO}_{4}^{2-}$ \\
\hline $\begin{array}{l}\text { Subcutaneous } \\
\text { spring }\end{array}$ & 17.4 & 615 & 7.8 & 391 & 139.2 & 6.6 & 0.1 & 1.2 & 10.0 & 0.3 & 5.2 \\
\hline Farfal spring & 12.6 & 582 & 7.1 & 337 & 115.4 & 7.2 & 2.1 & 2.6 & 11.3 & 12.9 & 6.3 \\
\hline Gutter & 12.9 & 497 & 7.5 & 297 & 99.2 & 5.4 & 0.7 & 2.0 & 9.4 & 2.8 & 4.1 \\
\hline
\end{tabular}

Table.1 Mean values of temperature, electrical conductivity (EC), pH and major ions concentrations. 